\title{
Why LATER WITTGENSTEIN WAS NOT A THERAPIST ${ }^{1}$
}

\author{
[Porque O SEGundo WitTGEnStein NÃo ERA UM TERAPEUTA]
}

\author{
Victor Loughlin * \\ University of Antwerp, Belgium
}

\begin{abstract}
Wittgenstein famously regarded philosophy as an activity and not as a body of doctrine. And yet within the secondary literature there is little agreement as to what Wittgenstein took the purpose of that activity to be. In this paper, I claim that the purpose of philosophical activity, at least according to the Later Wittgenstein, was to solve philosophical problems. As support for this claim, I argue that our everyday talk about the mind presents us with a philosophical problem about the mind. Focusing then on what Wittgenstein says about understanding and using his distinction between internal and external relations, I show how we can solve this problem. If my reading is accepted, then the purpose of philosophical activity, according to the later Wittgenstein, was not therapy. As such, later Wittgenstein should not be read as a therapist.
\end{abstract}

KEYWORDS: Wittgenstein; philosophy; therapy; mind; internal relations; external relations
Resumo: Wittgenstein ficou famoso por considerar a filosofia uma atividade e não um corpo de doutrinas. E, no entanto, na literatura secundária, há pouco acordo quanto ao que Wittgenstein considerou ser o propósito dessa atividade. Neste artigo, afirmo que o propósito da atividade filosófica, pelo menos de acordo com o segundo Wittgenstein, era resolver problemas filosóficos. Como suporte para essa afirmação, argumento que nossa conversa cotidiana sobre a mente nos apresenta um problema filosófico sobre a mente. Concentrando-me então no que Wittgenstein diz sobre a compreensão e usando de sua distinção entre relações internas e externas, mostro como podemos resolver esse problema. Se minha leitura for aceita, então o propósito da atividade filosófica, de acordo com o Wittgenstein posterior, não era terapia. Como tal, o segundo Wittgenstein não deve ser lido como um terapeuta.

Palavras-chaVe: Wittgenstein; filosofia; terapia; mente; relações internas; relações externas

\section{INTRODUCTION}

Tn one of only two books published in his lifetime (the other being a dictionary written while he was a school teacher in rural Austria), Wittgenstein wrote: "Philosophy is not a body of doctrine but an activity" (TLP 4.112). ${ }^{2}$ Throughout his lifetime, Wittgenstein held firm to this view. However, what did Wittgenstein take the purpose of that activity to be? Stern (2006) divides answers to this question into two camps: those who give a Pyrrhonian answer (Pyrrhonian Wittgensteinians) and those who give a non-Pyrrhonian answer (non-Pyrrhonian Wittgensteinians).

* Postdoctoral Research Fellow at Center for Philosophical Psychology, Dept. of Philosophy, University of Antwerp, Belgium. Email: victorloughlin@hotmail.co.uk. Orchid ID: 0000-0002$0885-214 X$ 
Pyrrhonian Wittgensteinians, as the name suggests, read Wittgenstein as someone profoundly skeptical of the remit of philosophy. Accordingly, "Wittgenstein offers us a form of skepticism that is aimed not at our everyday life, but at philosophy itself, with the aim of putting an end to philosophy and teaching us to get by without a replacement" (STERN, 217). Hence there are no real philosophical problems in need of solution. There are only confusions caused by "language going on holiday" (PI 38). And while philosophical investigation may help free us from captivating pictures (PI 115), it ultimately "leaves everything as it is" (PI 124). In short, the purpose of philosophical activity is to bring such activity to an end. Pyrrhonian Wittgensteinians, says Stern, include James Conant, Cora Diamond, Marie McGinn and (later) Gordon Baker.

As an example of a Pyrrhonian view, consider Crary and Reads' "New Wittgenstein" reading (CRARY \& READ, 2000). In her introduction to the book by the same name, Crary characterizes Wittgenstein (both early and late) as revealing the senselessness of thinking that philosophizing requires that we adopt some sort of external standpoint on language, that is, "a point of view on language as if outside from which we imagine we can get a clear view of the relation between language and the world" (ibid). This, says Crary, "is no more than an illusion of a point of view" (ibid). But if so, then rejecting this view is without consequence. For when we try and occupy this external view, "we don't succeed in articulating any thoughts" (ibid, emphasis in original). Consequently, just as nothing is gained by adopting such a view, then equally nothing is lost when we abandon that view. Wittgenstein is thus first and foremost a therapist, helping us "recognize that the idea of such a point of view [on language] creates the illusion of understanding the sentences we want to utter in philosophy" (ibid, emphasis in original).

By contrast, non-Pyrrhonian Wittgensteinians read Wittgenstein as developing positive solutions to genuine philosophical problems. As such, "Wittgenstein offers us [...] a logico-linguistic critique of past philosophy that makes a new philosophy within the limits of language possible" (STERN, 2006, 216). Philosophical activity thus does not leave everything as it is. For once we are reminded of the many things we say and do within our language-games, then we can come to see what we may otherwise not see because "it is always before [our] eyes" (PI 129). This in turn makes us better philosophers (STERN, 2006, 218). Non-Pyrrhonian Wittgensteinians, says Stern, include Peter Hacker and (early) Gordon Baker, David Pears and the Hintikkas.

As an example of a non-Pyrrhonian view, consider Stroll's reading (2002). According to Stroll, when Wittgenstein talks of "stopping doing philosophy" (PI 133), the philosophy Wittgenstein wants to stop doing is a particular way of philosophizing, which Stroll terms "traditional philosophy" (STROLL, 2002, 90). ${ }^{3}$ Traditional philosophizing, says Stroll, is characterized by its desire to "uncover the hidden, the covert principles that will allow us to make sense of the world as we find it" (ibid, 84). ${ }^{4}$ However, for Stroll's Wittgenstein, this way of philosophizing is problematic because nothing in our language-games is in fact hidden. The object then for the non-traditional philosopher is to follow the injunction, "don't think, but look!" (PI 66), that is, return philosophy to the "rough ground" (PI 107) or, as Wittgenstein puts it, "Not what one man is doing now, but whole hurly-burly, [...] against which we can see an action, and [which] determines our judgment, our concepts, and our reactions" (RPP II 629). This is how we solve those "deep disquietudes" (PI 111) or philosophical problems that may confront us.

This overview of the literature reveals the range of available answers to our initial question. For some, like Crary, the purpose of philosophical activity, according to 
Wittgenstein, is to dispel the particular illusions that philosophizing could conjure up. For others, like Stroll, the purpose of philosophical activity is to distance ourselves from a particular way of philosophizing i.e., traditional philosophy, which we do so by embracing a non-traditional Wittgensteinian approach to philosophical investigation.

In this paper, I will offer some evidence in favour of a non-Pyrrhonian view, at least as this view pertains to Wittgenstein's later work. In particular, I will offer evidence that supports Stroll's non-Pyrrhonian reading of Wittgenstein.

I begin by claiming that our everyday talk about our minds can present us with a philosophical problem about the mind. I then show how we can solve this problem. My solution has two parts. In the first part, I focus on some of Wittgenstein's remarks on understanding. Using Macha's (2015) account of Wittgenstein's distinction between internal and external relations, I show that clarifying what it means to understand requires looking at the particular circumstances within which we would say that someone understands. If so, then it is a mistake to assume that what happens at the moment someone understands thereby explains understanding. In the second part, I look at how we enact our talk about our minds. This clarifies that, for example, a statement about my mind has sense because of the internal relations between complexes that I am showing or displaying via my verbal and non-verbal bodily behaviours. If so, then it is a mistake to assume that something happens at the moment I make a statement (either inside or outside my head), which thereby explains my statement. However, given that this mistake is central to our original problem, then rejecting this mistake is to solve our philosophical problem.

I claim this two-part solution supports Stroll's reading of Wittgenstein. For we have solved our philosophical problem about the mind, not by uncovering any hidden or covert principles of the mind (the traditional approach), but rather by looking at the whole hurly burly against which we see an action (the non-traditional approach). If this reading is accepted, then Later Wittgenstein was no "New Wittgenstein" style therapist, which is to say that the purpose of philosophical activity was not therapy. Rather the purpose of philosophical activity, according to this non-Pyrrhonian reading of Wittgenstein, was to solve philosophical problems.

The layout of this paper then is as follows. In 2, I introduce an everyday example, which I claim raises a philosophical problem about the mind. In 3, I discuss some of Wittgenstein's remarks on understanding. In 4, I look at how we enact our talk about our minds and what impact this has on our philosophical problem.

\section{MindS ARE STRANGE THINGS}

My friend and I are in a coffee shop. The shop is busy with customers (this example is sadly set in pre-Covid times). Music is playing in the background. My friend is sitting across from me. Unprompted, I look down at my coffee and then I say to her, "I think I am losing my mind". How should she respond? I suspect (indeed I hope) she would respond with compassion. After all, if I am being in earnest (and for now let's take it as given that I am), then my statement is a cry for help, an admission that things in my life are beyond my control, that I am, as it were, lost in some mental fog.

However, let us pause and consider my statement. What exactly does it mean to say, "I think I am losing my mind"? Can minds even be things that are lost? Think of a coin. I can of course lose a coin. It can fall out of my pocket or I can otherwise misplace it. I can also take a coin out of my pocket and examine it. Yet I can't do anything equivalent with my mind. How then can I talk of losing my mind? 
We might reply that my statement is only metaphorical. Minds aren't literally things that can be lost. We just talk as if they were. Still, my statement does seem to suggest more than only a metaphorical way of taking. We are, I think most would agree, creatures with rich interior lives. Thus, when I talk of losing my mind, I can also mean that I am losing hold over my interior life, that is, I no longer have a steady grip on what is going on inside me. In which case, there is a sense in which such talk is on a par with losing a coin. For in both cases, some thing is indeed being lost, misplaced, no longer secure. As such, while the mind is of course not like a coin, it could still be a thing, albeit a strange kind of thing.

We might then decide to build on this idea. Consider what happened whenever I said to my friend, "I think I am losing my mind". It seems likely - indeed how could it be otherwise? - that something inside me must have prompted me to make my statement at that particular moment. Some inner turmoil, perhaps, raging inside my head. What should we make of this inner turmoil? One possibility is that we view it as a set of processes occurring inside my brain. Brain processes are clearly things with spatial and temporal dimensions. Now it seems we can make some real progress. For if my mind can be identified with processes occurring inside my brain, and these processes are things with well recognised spatial and temporal dimensions, then our previous idea was in fact correct, that is, my mind is indeed a thing. This strange thing just became a little less strange.

We could then apply this idea of ours to other uses of the word mind. I say, for example, "I am in two minds", meaning that I am undecided about some future decision. I say, "mind your head" or "mind the gap", thereby warning others to be careful where they place their heads or feet. I say, "oh, never mind!", when I am frustrated or angered by a conversation I am currently having with a friend (as I may do in the coffee shop if my friend does not respond in the way I hoped). Or I say, "oh don't mind that", by which I mean to dismiss the concerns of someone else. All these statements, so we may now think, are the result of processes occurring inside our brains. That is, whenever we say various things about our minds, there are processes inside our brains that explain why we decide to express ourselves in these different ways.

This idea has an obvious allure. For if it is correct, then we need no longer concern ourselves with the sorts of complexities and ambiguities that may surround the many statements that we make about our own minds and/or the minds of others. We can now just focus on what talk of mentality is really about, namely processes inside the brain. And given the ubiquity of talk of brains (at least in contemporary Western societies), then we may also feel that we have now gained a real purchase on what minds truly are. Simply put, minds just are processes in the brain.

However, a moment's reflection reveals that people don't usually refer to their brains when talking about their minds. More importantly, to insist otherwise requires ignoring the distinctive way in which talk of our minds features in our day to day lives.

Recall our previous examples. When I say, "I am in two minds", I don't mean I have two brain processes. I mean that I am undecided. Moreover, my indecision may be etched in the very furrowing of my brow, in how I raise my hands as if posing a question. When I say, “oh, never mind!”, I am not referring, even implicitly, to anything happening inside my head. I am instead expressing my frustration or anger at the actions of someone else. Moreover, my frustration may be present in the stamping of my feet, my anger displayed in the folding of my arms. This reminds us what is often so distinctive about our talk of our minds, namely that we rarely simply talk about our minds. More often than not, we instead enact our mental lives via what we say and do. 5 
What then of our previous idea of the mind as a thing? On the one hand, talk of our minds seems to require that we look inwards to what happens in the brain. Something inside us explains our various statements about our minds and this something must be - indeed it seems it can only be - a set of processes occurring inside our brains. On the other hand, once we do look inward, then we seem to lose what is so distinctive about such talk, namely that we often enact such talk. But then our minds are not things tucked away inside our skulls but instead displayed in what we say and do. These considerations thus demonstrate how an everyday statement about the mind - "I think I am losing my mind" - seems to leave us with a peculiar sort of problem, which can be formulated as a question, namely how are we to understand our talk about the mind?

Now, Wittgenstein took the view that philosophical problems "[have] the form: "I don't know my way about."” (PI 123). I claim that this is true of our problem. As the previous paragraphs have illustrated, when it comes to our talk about the mind, we seem to be both pulled inward and directed outward, in short, we don't seem to know our way about.

My aim in what follows is to show how we can solve this philosophical problem. My solution will have two parts. In the first part, I will focus on some of Wittgenstein's remarks on understanding. This will be the topic of the next section. ${ }^{6}$

\section{UNDERSTANDING}

In PI 150, Wittgenstein points out that the words "knows", "can", "is able to" and "understands" are "closely related". Suppose, for example, A writes down a sequence of numbers according to some hidden formula (PI 151). B closely watches what A does and then attempts to discern what this hidden formula is. Perhaps B pauses for a few moments but is then able to continue the number sequence. Plausibly, B has now understood the sequence. What then does B's understanding consist in (PI 152, 153)?

Wittgenstein considers various possibilities. Perhaps B tries out various formulae in her head until she hits on the one that fits the sequence. Or perhaps B does not think of any formulas at all but simply feels a certain tension and various thoughts occur to her. Or maybe B just has the thought "that's easy!" and then proceeds to give the answer.

However, as Wittgenstein makes clear, none of these possibilities answer our original question. For any one of these possibilities could have occurred and B might not have understood. Moreover, even if there was something common to all of these possibilities, we may still wonder why that common element and not something else should qualify as understanding. Indeed, if that common element was itself hidden from B, how could it be the source of her understanding? As Wittgenstein notes, these worries seem to leave us in a muddle (PI 153).

Yet this muddle or confusion arises, insisted Wittgenstein, because we assume that something must have happened at the moment $\mathrm{B}$ considered the number sequence that explains B's understanding of the sequence. This is the picture that captivates us. We can break the hold this picture has over us once we instead remind ourselves that B's understanding of the sequence consists in those particular circumstances that we call "understanding the number sequence" (PI 154).

However, we may wonder what Wittgenstein is doing here. As stated above, we already know what circumstances must occur for B to have understood the formula. 
Plausibly B only understands the number sequence if B can continue the sequence. But if this is true, then how does reminding ourselves of this fact help us?

I propose to answer this question by introducing some remarks on Wittgenstein's notion of internal relations and external relations. ${ }^{7}$ An arguably comprehensive account of how such relations feature in Wittgenstein's later work comes from Macha (2015). ${ }^{8}$ According to Macha, internal relations, as opposed to external relations, have five interconnected characteristics.

First, such relations hold between concepts. Note that the term 'concept' is not to be understood as referring to some interior mental item. For Macha, concepts are best understood as complexes, which can be facts, actions, practices or types of behaviour (ibid, 84). Importantly, the internal relations between these different relata can only be shown or displayed via the complexes themselves. In this sense, internal relations are exhibited via what we say and do and so can be perceived by others. ${ }^{9}$

Second, internal relations, says Macha, "hold in virtue of grammar. Grammatical propositions are either explicit statements of the grammar of a language-game or also in Wittgenstein's final texts - implicit descriptions of our human form of life" (ibid, 83). Internal relations are thus "exhibited in grammatical propositions" (ibid 102). Another way of putting this is to say that internal relations can be understood as the rules that logically structure our language-games.

Third, internal relations are timeless or non-temporal. Wittgenstein makes this point when he says that an internal relation "holds if the terms are what they are, and which cannot therefore be imagined not to hold" $(\mathrm{PO}, 86)$. That is, as long as the relata involved exist or are present, then the internal relation between those relata is not dependent upon any extraneous factors. This is in contrast to external relations, since such relations are expressed by sentences whose "truth or falsity depends on accidental circumstances which are, of course, time-dependent" (MACHA, 2015, 94). Indeed, Macha refers to this as the "criterion of temporality" (ibid, 93). He writes: "This criterion gives us a tool or method for determining whether a given sentence expresses an internal or external relation in a given language-game" (ibid, 97).

Fourth, complexes that are internally related are not mediated or linked via any third items. Such complexes thus "relate their terms only in virtue of these very terms, not in virtue of other things or rules" (ibid, 102). Macha also states: "the terms of an internal relation are related directly, without any mediation, to each other" (ibid, 97). This ties together with the third characteristic. For if the complexes that are internally related exist or are present, then there are no extraneous factors, like a third item or items, which mediate between or link these complexes.

Fifth and finally, internal relations allow no exceptions (ibid, 102). This also ties together with the third characteristic. For if internal relations are timeless or nontemporal, then, in contrast to external relations, there can be no circumstances under which an internal relation would not hold, since if there were such circumstances, then the relation involved would not be internal but rather external.

With this summary of internal relations in place, I now return to our initial question, which was this: how does reminding ourselves of the circumstances when we would say B has understood the number sequence help us? Using the distinction between internal and external relations, we can now answer this question.

For example, when writing down the number sequence and asking $\mathrm{B}$ to discern the hidden formula governing these numbers, A's action is grammatical. For A is showing or displaying an internal relation between two complexes, namely the number sequence and the formula that governs that sequence. The skill or technique that B must thus acquire is the ability to see this internal relation. In which case, the learning 
involved here is not a matter of internal ratiocination or inference..$^{10} \mathrm{It}$ is rather a matter of visual perception. B must learn to see what A is doing. Once B can see what A is doing, then $\mathrm{B}$ can determine the complexes involved and so can continue the number sequence.

If this is correct, then this explains why none of the possibilities sketched earlier - B tries out various formulas in her head, B feels a certain tension and various thoughts occur to her or B simply thinks, "That's easy!" - can explain B's understanding. Recall Macha's criterion of temporality. As we saw, this gives us a way of determining whether there are internal or external relations involved in a language-game. Using this criterion, we can say that the possibilities discussed above only identify an external relation between $\mathrm{B}$ and the number sequence, that is, a set of accidental circumstances that need not have occurred. This is because all of these possibilities are time dependent, that is, they occur at the moment B considers the number sequence. However, since these possibilities only identify an external relation, then any of these possibilities could have occurred and B would still not have understood the number sequence. In which case, these possibilities cannot help us explain the fact that B has understood the number sequence.

Thus, by reminding ourselves of the circumstances when we wolud say B has understood the number sequence, we can clarify what it means for B to have understood the number sequence. B's understanding consists in B's ability to see the internal relation between the complexes that $\mathrm{A}$ is showing or displaying. If so, then it is a mistake to think that B's understanding consists in anything occurring at the moment B considers the number sequence. For anything could occur at this moment and B still not have understood, since any such occurrence would only identify an external relation between $\mathrm{B}$ and the number sequence.

This is the first part to my two-part solution to our philosophical problem. I now turn to the second part.

\section{ThINKING}

Think back to our philosophical problem. Talk of minds seems to direct us inwards towards what happens in the brain. Something inside me explains why I said, "I think I am losing my mind" and this something must be a set of processes occurring inside my brain. Yet once we do look inward, then we seem to lose what is so distinctive about such talk, which is that we often enact such talk. But then our minds are not things tucked away inside our skulls but instead displayed in what we say and do. How then are we to understand our talk about the mind? This was our philosophical problem.

In the first part of my two-part solution to this problem, I showed that clarifying what it means to understand requires looking at the particular circumstances within which we would say that someone understands. If so, then it is a mistake to assume that what happens at the moment someone understands thereby explains understanding. In this second part, I will now look at how we enact our talk about our minds.

To begin, let us look at the particular circumstances within which it makes sense to say, "I think I am losing my mind". In more detail, let us focus on those circumstances when it would make sense for you to call my statement 'thoughtful'. These circumstances could be the following.

You could ask me why I feel the way I do and I might say things like, "I am having problems with my boss" or "I am having marital difficulties" or "I just received 
some worrying blood tests from the doctor". These latter statements would justify your characterisation of my statement, since these latter statements of mine would count as reasons for my initial statement. Using the distinction between internal and external relations, we can see why this is so. These latter statements count as reasons because of the internal relations between the complexes involved, namely the internal relations between my initial statement, "I think I am losing my mind" and these various follow up statements. In which case, my verbal behaviour here is grammatical, that is, the things I say in support of my initial statement show or display internal relations between these statements. It is thus your perception of these internal relations that supports your characterisation of my initial statement as 'thoughtful'.

However, suppose I offer no verbal support for my statement. I instead simply express myself in such a way that there is no doubt in your mind that I am being genuine. For example, I may make my statement while looking utterly dejected, confused, tired or lost. There may be tears in my eyes, my mouth may be twisted in pain or my shoulders may be slumped forward in defeat. I may shout out my statement, signalling my utter exasperation. Or I may whisper it like a shameful realization. You could take any of these actions of mine as evidence that I was being genuine when I said, "I think I am losing my mind".

As before, these bodily actions of mine count as reasons for my statement because they are grammatical, that is, they show or display internal relations between complexes. For when I express myself in such a way that there is no doubt about my genuineness (tears in my eyes, twisted mouth, slumped shoulders, unusually loud or quiet voice etc), I am showing or displaying an internal relation between various complexes, in this case between my verbal statement, "I think I am losing my mind" and these non-verbal bodily behaviours. Hence even if I provide no verbal support for my statement, my bodily behaviour may be all the support my statement needs. And this is because I am showing or displaying internal relations via what I am saying and doing. It is consequently your perception of these relations that convinces you that I am being genuine.

Of course, when I make my statement, I could in fact be lying about how I am actually feeling. Perhaps I in fact feel fine and I am simply making my statement in order to elicit sympathy from you. But, as Wittgenstein points out, "That seems genuine" only makes sense if there is a "That is genuine" (LW II 86e). That is, I am only able to deceive you on this occasion because, on other occasions (like the occasion sketched in the previous paragraph), there are internal relations between complexes such that there is no doubt about my genuineness. Contrarily, if there were no such occasions where my genuineness was not in doubt, then the very notion of genuineness would cease to make sense.

This reveals, says Wittgenstein, that "[w]e are playing [here] with elastic, indeed even flexible concepts" (ibid 24e). But this doesn't mean that such concepts "can be deformed at will and without offering any resistance, and [are] therefore unusable. For if trust and distrust had no basis in objective reality, they would be of pathological interest" (ibid, emphasis in original). That is, our concepts are products of the "complex nature and the variety of human contingencies" (RPP II 614) and "The importance we attach to the subtle shades of behaviour" (ibid, 616). Such subtle shades of behaviour provide the wellspring from which our concepts are drawn. The internal relations I am showing or displaying on this and other occasions supports this point. For such relations are, as Macha makes clear, "implicit descriptions of our human form of life" (MACHA, 2015, 83).

We are in a position then to clarify what it means to enact our talk about our 
minds. In our example, it means that I am showing or displaying internal relations between various complexes via my verbal and non-verbal bodily behaviours. You in turn perceive these relations and it is your perception of these relations that convinces you either to regard my statement as 'thoughtful' or simply that I am being genuine when I make my statement. This clarification then shines a new light on our philosophical problem about the mind, as I will now demonstrate.

Consider that the assumption central to that problem was the idea that something must happen at the moment I make my statement, "I think I am losing my mind" and this something must be a set of processes occurring inside my brain. In order to examine this assumption, we first need to demarcate the plethora of processes that may be active in my brain at the moment I make a statement from those brain processes, which, so our problem assumes, are what explain my statement.

For the sake of argument then, let us imagine that a skilled neuroscientist has access to my brain at the moment I make my statement and this neuroscientist can observe the multitude of happenings occurring inside my brain. This neuroscientist then identifies a set of processes in my brain, which, so they claim, are what explain why I made my statement. Armed with our previous clarification, we can say two things in response to this claim.

First, while the neuroscientist may be correct in their identification of the processes active in my brain at the moment I make my statement, this does not demonstrate, second, that such processes explain my statement. Recall Macha's criterion of temporality. In our discussion of understanding, we used this criterion to show that whatever happened at the moment B considered the number sequence could not explain the fact that B understood, since any such momentary happenings could occur and B still not have understood (see section 3). A similar point can be raised here. Consider that any processes active in my brain at the moment I make my statement are temporal. As such, any relation between such processes and my verbal statement must be external. Given that this relation is external, then any of these processes could have occurred and I may still not have made my statement. In which case, no description of my brain at the moment I made my statement, no matter how detailed or complex, can explain why I made my statement. To think otherwise is to confuse an external relation for an internal one. ${ }^{11}$

If so, then it is a mistake to assume that there is a set of processes occurring in my brain at the moment I make my statement and this set of processes explains my statement. Rather, as we saw before, explaining my statement requires either looking at the reasons I give for my statement or examining my bodily behaviour as I make my statement. None of this is of course to deny the importance of the brain. Rather it shows that it is false to assume that the neuroscientist could identify a set of processes occurring inside my brain that, by dint of these processes alone, explains my statement about my mind. ${ }^{12}$

However, an objection to this claim might be the following. As we saw above, I may make my statement in such a way that there is no doubt in your mind that I am being genuine (tears in my eyes, twisted mouth etc). This all happens at the moment I make my statement. But if so, then even if it is correct to reject the assumption that some set of processes occurring in my brain explains my statement, what is happening at the moment I make my statement still explains why you take me to be genuine when I make my statement.

Yet this objection fails to recognise the internal relations involved. For it is the internal relation between my statement and my non-verbal bodily behaviours, which ensures that my non-verbal bodily behaviours qualify as reasons that I am being 
genuine. These non-verbal behaviours are thus grammatical and, so are tied in a noneliminable fashion to the wider language-game (see the second characteristic on Macha's list, as given in section 3). Thus, even though these non-verbal behaviours occur at the moment I make my statement, what makes these behaviours count as reasons for my genuineness cannot be fixed to that moment but rather must be understood as including the wider language-game.

We now have a solution to our philosophical problem of the mind. Using the distinction between internal and external relations, we clarified what it means to enact our talk about our minds. This clarification revealed that it is a mistake to assume that something happens at the moment I said, "I think I am losing my mind", which thereby explains my statement. For anything could occur at this moment (either inside or outside my head) and this would still not explain my statement, since any such occurrence would only identify an external relation between this occurrence and my statement. Given that this mistake is central to our problem, then rejecting this mistake is thus to solve our problem. Crucially however, this solves our problem, not by uncovering some hidden or covert principles of the mind, but rather by looking at the whole hurly burly against which we judge an action.

\section{Conclusion}

I began this paper by noting the different answers to the question, what did Wittgenstein take the purpose of philosophical activity to be? On the one hand, Pyrrhonian Wittgensteinians answer that Wittgenstein sought to dispel the illusions that philosophy can conjure up. On the other hand, non-Pyrrhonian Wittgensteinians answer that Wittgenstein sought to end traditional philosophy by embracing a non-traditional approach to philosophical investigation. A proponent of this latter view was Stroll.

I have now offered some evidence in favour of Stroll's reading. This evidence involved identifying a philosophical problem about the mind and then, focusing on what Wittgenstein says about understanding and using his distinction between internal and external relations, showing how we can solve this problem, which we did so by looking at the whole hurly burly against which we judge an action.

This then supports a non-Pyrrhonian view of Later Wittgenstein. That is, it supports reading Later Wittgenstein in such a way that the purpose of philosophical activity was not therapy. Wittgenstein so understood was no "New Wittgenstein" style therapist. Instead, the purpose of philosophical activity, according to the nonPyrrhonian reading defended in this paper, was to solve philosophical problems.

\section{REFERENCES}

BAZ, A. Wittgenstein on aspect perception. Cambridge: Cambridge University Press, 2020.

CRARY, A.; READ, R. (Eds.) The new Wittgenstein. London; New York: Routledge, 2000.

GLOCK, H. A Wittgenstein dictionary. New York: Blackwell Publishers, 1996.

LOUGHLIN, V. Why enactivists should care about Wittgenstein. Philosophia, 2020. (Ahead of print) https://doi.org/10.1007/s11406-020-00286-3.

MACHA, J. Wittgenstein on internal and external relations: tracing all the connections. London; New York: Bloomsbury Academic, 2015.

MOYAL-SHARROCK, D. Wittgenstein's razor: the cutting edge of enactivism. American Philosophical Quarterly, v. 50, n. 3, p. 263-279, 2013.

MOYAL-SHARROCK, D. The myth of the quietist Wittgenstein. In: BEALE, J.; KIDD, I. (Eds.) Wittgenstein and scientism. London; New York: Routledge, 2017. p. 152-174.

STERN, D. How many Wittgensteins? In: PICHLER, A.; SAATELA, S. (Eds.) Wittgenstein: the 
philosopher and his works. Frankfurt: Ontos Verlag, 2006. p. 205-229.

STROLL, A. Wittgenstein. London: Oneworld Publications, 2002.

SUSSWEIN, N.; RACINE, T. R. Wittgenstein and not-just-in-the-head cognition. New Ideas in Psychology, v. 27, n. 2, p. 184-196, 2009.

WITTGENSTEIN, L. Remarks on philosophical psychology - v. 2. Chicago: University of Chicago Press, 1988. (RPP II)

WITTGENSTEIN, L. Last writings on the philosophy of psychology: the inner and the outer, vol 2. London; New York: Blackwell Publishing, 1992. (LWII)

WITTGENSTEIN, L. Philosophical Occasions: 1912-1951. Edited by J. Klagge and A. Nordmann. Indianapolis; Cambridge: Hackett Publishing Company, 1993. (PO)

WITTGENSTEIN, L. Tractatus logico-philosophicus. London: Routledge, 2001. (TLP)

WITTGENSTEIN, L. Philosophical investigations. Oxford: Wiley-Blackwell, 2009. (PI)

\section{ABbreViations FOR WitTGEnSTEIN'S WORKS}

TLP = Tractatus Logico-Philosophicus;

$\mathrm{PI}=$ Philosophical investigations;

$\mathrm{PO}=$ Philosophical Occasions;

LW II = Last Writings on Philosophical Psychology, volume 2;

RPP II = Remarks on Philosophical Psychology, volume 2.

\section{Notas}

1 Thanks to two anonymous reviewers whose comments helped develop and improve the argument of this paper. This research was funded by the Research Foundation Flanders (FWO), Project 1209616N, "Removing the Mind from the Head. A Wittgensteinian perspective".

2 I shall be using the following abbreviations to refer to works by Wittgenstein: TLP = Tractatus Logico-Philosophicus; PI = Philosophical investigations; PO = Philosophical Occasions; LW II = Last Writings on Philosophical Psychology, volume 2; RPP II = Remarks on Philosophical Psychology, volume 2. Further details about these works can be found in the bibliography of this paper.

3 Glock (1996) agrees with Stroll: "Wittgenstein was right to think of his methodological views as novel and radical. They run up not just against the scientific spirit of the twentieth century (CV 6-7) but against the whole history of philosophy" (ibid, 292).

4 Wittgenstein's method does have a distant lineage within the philosophical tradition, however. Stroll (2002) writes: "[Wittgenstein] is doing something that the pre-Socratics would have found congenial. Many of these early philosophers, Thales, Anaximander, Heraclitus, and Democritus, were interested in giving an accurate account of reality. Their methods and their results were primitive by today's sophisticated standards; but the notion that philosophy can and should describe the world is a presupposition they share with Wittgenstein. But having said that, one must also stress that Wittgenstein's method is wholly different from anything we find in any writer before him" (ibid, 82-83).

5 Some might take issue with the claim that we enact our minds via what we say and do. However, Wittgenstein arguably took a similar view. He wrote: "Consciousness in the face of another. Look into someone else's face and see the consciousness in it, and also a particular shade of consciousness. You see on it, in it, joy, indifference, interest, excitement, dullness. The light in the face of another. (RPP I 927) He also wrote: "We see emotion' - As opposed to what? - We do not see factual contortions and make the inference that he is feeling joy, grief, boredom. We describe the face immediately as sad, radiant, bored, even when we are unable to give any other description of the features." (RPP II 570).

6 I accept that the discussion of Wittgenstein's remarks on understanding that I give here (see section 3 of the paper) is highly selective. I think this is justified, however. For my aim to 
not provide a full treatment of these remarks but rather to provide evidence for a nonPyrrhonian reading of Wittgenstein. A partial treatment of these remarks, so I would argue, is sufficient to support this point.

7 For a detailed description of how internal and external relations feature in the secondary literature on Wittgenstein, see Loughlin, 2020.

988 Macha (2015) distances himself from resolute readings of Wittgenstein (what, following Stern, I have called "Pyrrhonian" readings) by claiming that, "Witttgenstein's method of analysis [is] a kind of philosophical theory, although this clashes with Wittgenstein's desire not to offer theories. [...] This theory is not, however, a theory of a primary order. It introduces a procedure for how to deal with other philosophical theories - a sort of transcendental theory." (ibid ix) Although I do not use Macha's analysis as a procedure for dealing with other theories, the non-resolute nature of his analysis nonetheless supports using it to develop a non-Pyrrhonian reading of Wittgenstein, as I do in this paper.

9 Baz (2020) makes a similar point: "Two (or more) perceived things (objects, elements) stand in an internal relation to each other when their perceived qualities are not independent of the perceived relation between them, or, in other words, when how each one of them perceptually presents itself affects how the other perceptually presents itself" (ibid, 20). An internal relation is thus a "perceptual notion", says Baz.

10 Moyal-Sharrock (2013) makes it clear that, for Wittgenstein, learning is first and foremost not a cognitivist operation. Rather, learning involves training, that is, the acquiring of a set of embodied and embedded skills and techniques. And acquiring these skills and techniques is learning how to act. Moyal-Sharrock's (2017) also characterises Wittgenstein as a "militant, interventionist philosopher" (ibid, 169). I take these remarks of hers to support my non-Pyrrhonian reading of Wittgenstein.

11 Susswein and Racine (2009) make a similar point when they note that an Augustinian account of language, whereby words are correlated with the objects they represent, "appears to conflate the empirical relation of correlation with the logical relation of representation" (ibid, 189). The neuroscientist in our example does something akin to this, that is, they conflate an external relation between two objects e.g., processes in the head and a verbal statement, for an internal relation between two complexes e.g., verbal statements and non-verbal bodily behaviours.

12 The neuroscientist might concede that all they need is to identify a correlation between these processes in my brain and my statement. However, even under these circumstances, the neuroscientist could not claim to identify a set of processes occurring inside my brain that, by dint of these processes alone, explains my statement about my mind. For they would still need to differentiate the processes that are correlated with my statement from the plethora of other processes that are also ongoing in my brain. This differentiation will likely require invoking criteria for assessing the different functional roles of parts of the brain. Such criteria will in turn reference the wider linguistic and social practices in which neuroscientists are engaged, since it is only via such practices that it makes sense to divide up the brain in this manner. But if so, then the assumption central to our philosophical problem can still be rejected, since it is only via these wider practices (and not on the basis of the processes alone) that the neuroscientist can claim to have identified such a correlation. 